\title{
Phenology of Four Varieties of Gooseberry (Physalis peruviana L.) in Greenhouses and Hydroponics for its Commercial Production in Mexico
}

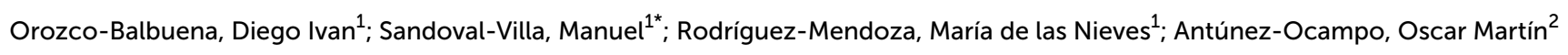

${ }^{1}$ Colegio de Postgraduados, Programa de Edafología Campus Montecillo, Texcoco, Estado de México. ${ }^{2}$ Campo Experimental Iguala, INIFAP. Iguala, Guerrero, México.

*Corresponding author: msandovalacolpos. $m x$

\section{ABSTRACT}

Objective: To measure the phenology, morphology and development of four varieties of Physalis peruviana L. under greenhouse and hydroponics conditions, by effect of the ionic strength of the Steiner nutrient solution for cultivation in Mexico.

Design/Methodology/Approach: The research was conducted under a completely random design with factorial arrangement, the treatments evaluated resulted from the combination of the levels of the variety factor (Colombia, Sacha, Chiclayo and Modified) with the levels of the ionic strength of the Steiner nutrient solution (50, 100 and 150\%), and the experimental unit was a potted plant. For phenology each phase was recorded in the plants, SPAD readings were taken in the vegetative stage, for diameter and height several samples were taken, and $\mathrm{pH}$ and electrical conductivity were accomplished on stems and petioles of shoots of each treatment. An analysis of variance and the comparison of means per Tukey ( $\mathrm{p} \leq 0.05$ ) were implemented with the SAS 9.2 program.

Results: The varieties under study showed differences in the time of occurrence of the phenological stages. SPAD readings, basal diameter, $\mathrm{pH}$ and electrical conductivity in sap were affected by each factor except for the interaction. Meanwhile, plant height was significantly affected in the first 24 days after transplant (dat) by the combination of the two factors.

Study Limitations/Implications: The results obtained are limited to the varieties, the environmental conditions, and the time when the varieties were evaluated.

Conclusions: The phenology of each variety was not expressed at the same time in any concentration, as an early variety was given to Chiclayo, Colombia and Sacha, which are varieties that in the concentrations 50 and $150 \%$ of the nutrient solution started harvesting at 99 dat.

Keywords: gooseberry, phenology, morphology, hydroponics

\section{Agroproductividad: Vol. 14, Núm. 3, marzo. 2021. pp: 3-9.} Recibido: julio, 2020. Aceptado: enero, 2021. 
INTRODUCTION

Gooseberry native to the South American Andes, known for being tolerant to different environmental conditions and able to adapt to different types of soil (Góngora and Rojas, 2006).

In Mexico, this species is known as Peruvian cherry or "uchuva" (Morton, 1987); however, there are very few studies focused on its adaptation to distinct climates, soils, plagues and diseases (Gastelum, 2012). There is only the study by Mora et al. (2006), which characterized six species of $P$. peruviana. These researchers found significant genotypic differences between fruits collected in terms of fruit yield, fresh fruit weight with and without calyx, growth habit, height of first bifurcation, stem diameter, and number of leaves.

The available published information only focuses on the agronomic management of the Colombia variety; for example nourishment with different concentrations of Steiner solution (Gastelum et al., 2013), application of different proportions of ammonium and nitrate in plants grown from seed, regrowth and cutting (Antúnez et al., 2016), and phenological behaviour in the field and in greenhouses (Sabino et al., 2016). Due to the aforementioned, it is important to evaluate the productivity of other varieties, since there are excellent opportunities in select markets. Therefore, the objective of this study was to measure the phenology, morphology and development of varieties of Physalis peruviana $L$. under greenhouse and hydroponic conditions, resulting from different percentage concentrations of Steiner nutrient solution.

\section{METHODS AND MATERIALS}

\section{Experiment location}

The study was carried out in a greenhouse from the Plant Nutrition Area of Colegio de Postgraduados in the Montecillo campus, located at kilometer 36.5 of the Mexico-Texcoco highway in Montecillo, Texcoco, in Estado de México from May until December 2019. The study was developed in a $50 \mathrm{~m}^{2}$ greenhouse with overhead ventilation and side curtains, with a galvanized steel structure covered in UVII-720 polyethylene. It is located on coordinates $19^{\circ} 27^{\prime} 41.0^{\prime \prime}$ North latitude and $98^{\circ} 54^{\prime} 32.2^{\prime \prime}$ West latitude, at an altitude of 2,243 m.

\section{Plant Material}

In order to carry out this experiment, the Sacha and Modified variety were brought in from Ecuador, the Chiclayo variety from Peru and the Colombia variety is the one that has been used in the institution, with a germination rate of $80 \%$. The seeds were sown in styrofoam trays with 200 cavities filled with peat moss as a substrate, placing one seed per cavity and moistened each day with tap water.

\section{Substrate Preparation and Bag Filling}

Red tezontle was sifted in order to obtain particle size between 5 to $7 \mathrm{~mm}$, which was then disinfected with sodium hypochlorite $\left(\right.$ Cloralex $\left.^{\circledR}\right)$ in a $1: 10$ proportion; requiring three rinses with tap water. Afterwards, $40 \times 40$ $\mathrm{cm}$ black polyethylene bags were filled, which were previously perforated in order to allow water to drain.

Transplant. This step was carried out when the plants reached a height of $10 \mathrm{~cm}$ and a good amount of roots, which occurred 56 days after sowing (das).

Pest Control. Prepared solutions were sprayed containing garlic extract at a dose of $75 \mathrm{~mL} 15 \mathrm{~L}^{-1}$ of water, for cabbage looper pupa (Trichoplusia ni Hubner).

\section{Treatment and Experimental Design}

The experiment was established on July 26, 2019. It was carried out in a completely randomized design (CRD) with factorial arrangement, the treatments evaluated were the combination of the variety factor (Colombia, Sacha, Chiclayo and Modified) with the levels of Steiner nutrient solution concentration (50, 100 and 150\%), and the experiment unit was one plant per pot.

\section{Nutrient Solution}

In order to implement the treatments, three $1000 \mathrm{~L}$ capacity tanks were used, in which universal Steiner nutrient solution (1984) was prepared in three different concentrations, adjusting $\mathrm{pH}$ levels between 5.5 and 6.5 and using sulfuric acid. Irrigation with the nutrient solution was carried out six times a day, with duration of 10 minutes each, by means of drip irrigation.

\section{Study Variables}

\section{Phenology Registry}

The phenology registry is described next. Days to flowering: the number of days elapsed between emergence of seedlings until the release of the first 
flower were counted. Days to anchoring: the days since emergence until the recently formed fruit were counted. Days to physiological maturity: counted from the emergence of the plant until the fruit turns yellow color Days to production: counted from the emergence until the fruit harvest from each plant began.

SPAD Readings. Using a portable SPAD-502 Minolta ${ }^{\circledR}$ meter, the leaves greenness index was determined at 46 das; during each treatment repetition, a SPAD reading was performed in each cardinal point in the medial stratum of the plant and the average per plant was measured.

Electrical Conductivity and Sap pH. Stems and petioles were cut from buds from each treatment, and then they were chopped as finely as possible in order to be placed into a blender and ground at low speed. Afterwards it was passed through an anti-aphids mesh and manual pressure was applied in order to obtain $40 \mathrm{~mL}$ of sap, of which samples were taken.

Stem Basal Diameter. A digital Vernier was used to measure the stems thickness at 52 days after transplant (dat), which coincides with the plants' vegetative and reproductive stages.

Plant Height. A metric tape was used to measure, using the neck of the stem as the base and up to the longest measurable branch that it was possible to measure.

Statistical Analyses. An analysis of variance and Tukey's means comparison test ( $p \leq 0.05)$ were used for each of the response variables, using the statistical software SAS (SAS Institute, 2002).

\section{RESULTS AND DISCUSSION Morphology}

Of the four varieties evaluated, three had different morphology in some of their organs when compared to Colombia, which is the variety that all previous studies have been done on. Subsequently, the differences among the varieties are described. Chiclayo: Calyx with five ribs and an elongated shape, with fruit with a diameter between 17-22 mm. Sacha: Heavily veined calyx with 6-7 ribs, fruit with a diameter between 17$25 \mathrm{~mm}$. Modified: Very pubescent stems with a purple color with short internodes, pubescent leaves ranging in size from 5-12 cm long and 6-10 cm wide, a brown color calyx in ripening with fruits of 10-18 cm diameter, with a greenish brown color, with similar flavor to shell tomatoes (Physalis ixocarpa Brot.).

\section{Phenology}

The different varieties in the study showed differences in the timing of phenological stages. The phenology of the Chiclayo variety (Figure 1) in the vegetative and reproductive stages showed the same tendencies with the three solutions, the phases were expressed almost simultaneously, yet the production phase was out of synch with the Stenier solution at $100 \%$. The fruits of these plants treated ripened on average 104 days after transplant (dat).

With Steiner solution at $100 \%$ the Colombia variety (Figure 2) went ahead of the rest in the productive stage in 7 days, which means it was the most precocious. Concentration at $150 \%$ showed a similar ripening for Chiclayo (Figure 1), Colombia (Figure 2) and Sacha varieties (Figure 3) which on average ripened at 99 dat.

\begin{tabular}{|c|c|c|c|c|c|c|c|}
\hline \multicolumn{7}{|l|}{$\begin{array}{l}\text { Chiclayo } \\
\text { Variety }\end{array}$} & \\
\hline \multirow{2}{*}{$\begin{array}{c}\text { Steiner's } \\
\text { nutrient solution } \\
\text { concentration (\%) }\end{array}$} & \multicolumn{3}{|c|}{ Vegetative stage } & \multicolumn{3}{|c|}{ Reproductive stage } & Fruiting stage \\
\hline & $\begin{array}{l}\text { Germination } \\
\text { (das) }\end{array}$ & $\begin{array}{c}\text { Transplant } \\
\text { (das) }\end{array}$ & $\begin{array}{c}\text { Preflowering } \\
\text { (ddt) }\end{array}$ & $\begin{array}{l}\text { Flowering } \\
\text { (dat) }\end{array}$ & $\begin{array}{c}\text { Fruit set } \\
\text { (dat) }\end{array}$ & Ripening (dat) & Fruiting (dat) \\
\hline 50 & 22 & 56 & 23 & 31 & 41 & 92 & 99 \\
\hline 100 & 22 & 56 & 26 & 33 & 44 & 93 & 104 \\
\hline 150 & 22 & 56 & 25 & 30 & 41 & 91 & 99 \\
\hline
\end{tabular}

Figure 1. Phenological stages in function of the concentration of Steiner solution in the Chiclayo variety. 


\begin{tabular}{|c|c|c|c|c|c|c|c|}
\hline \multicolumn{8}{|l|}{$\begin{array}{l}\text { Colombia } \\
\text { Variety }\end{array}$} \\
\hline \multirow{2}{*}{$\begin{array}{l}\text { Steiner's } \\
\text { nutrient solution } \\
\text { concentration (\%) }\end{array}$} & \multicolumn{3}{|c|}{ Vegetative stage } & \multicolumn{3}{|c|}{ Reproductive stage } & Fruiting stage \\
\hline & $\begin{array}{l}\text { Germination } \\
\text { (das) }\end{array}$ & $\begin{array}{l}\text { Transplant } \\
\text { (das) }\end{array}$ & $\begin{array}{l}\text { Preflowering } \\
\text { (ddt) }\end{array}$ & $\begin{array}{l}\text { Flowering } \\
\text { (dat) }\end{array}$ & $\begin{array}{l}\text { Fruit set } \\
\text { (dat) }\end{array}$ & Ripening (dat) & Fruiting (dat) \\
\hline 50 & 22 & 56 & 24 & 29 & 39 & 93 & 100 \\
\hline 100 & 22 & 56 & 21 & 26 & 37 & 87 & 93 \\
\hline 150 & 22 & 56 & 24 & 28 & 39 & 90 & 99 \\
\hline
\end{tabular}

Figure 2. Phenological stages in function of the concentration of Steiner solution in the Colombia variety.

\begin{tabular}{|c|c|c|c|c|c|c|c|}
\hline \multirow{2}{*}{$\begin{array}{c}\text { Steiner's } \\
\text { nutrient solution } \\
\text { concentration (\%) }\end{array}$} & & & & & & $t_{1}$ & \\
\hline & \multicolumn{3}{|c|}{ Vegetative stage } & \multicolumn{3}{|c|}{ Reproductive stage } & Fruiting stage \\
\hline 50 & 11 & 56 & 22 & 30 & 41 & 87 & 99 \\
\hline 100 & 11 & 56 & 22 & 30 & 41 & 90 & 102 \\
\hline 150 & 11 & 56 & 19 & 26 & 36 & 85 & 97 \\
\hline
\end{tabular}

Figure 3. Phenological stages in function of the concentration of Steiner solution in the Sacha variety.

For the Modified variety, none of the three solution concentrations showed any advantage in terms of the productive stage when compared to the rest, with a difference of 10 to 15 dat for fruit ripening (Figure 4). The contrasting result for this variety compared to the others could be due to genetic variability. This is attributed to the significant difference in this variety when compared to the rest, with its morphology more similar to shell tomatoes (Physalis ixocarpa Brot.).

For their part, Mora et al. (2006) found that flowering, development and physiological fruit ripening in some wild P. peruviana initiated at 42, 52 and 102 dat, which does not coincide with that found in these varieties collected from greenhouses. The varieties studied were more precocious in every stage. Other authors indicate that the start of flowering began at 60 dat and fruit took around 120 dat to fully ripen (Ali and Singh, 2014). These variations depend on environmental factors where the studies were carried out.

\section{SPAD Readings}

The analyses of variance showed significant differences (Tukey, P $\leq 0.05$ ) for the SPAD readings, which were detected by the variety and the nutrient solution, while for the interaction between variety and solution the SPAD readings were not affected (Figure 5). For their part, the variety with the highest SPAD readings was Sacha (52.69) and the lowest was Modified (49.78 b), while the nutrient solution at $150 \%$ reported the highest readings (54.06 a) and the lowest with 50\% (49.78 b). The SPAD readings were $52.23 \mathrm{a}, 52.24 \mathrm{a}, 49.78 \mathrm{~b}$ and 52.69 for Chiclayo, Colombia, Modified and Sacha respectively with the means test (Tukey, $p<0.05$ ). Regarding the concentration of the solution shown in Figure 5, it is evident that it is directly proportional to the SPAD readings. Sánchez (2019) evaluated the effect of the three concentrations of Steiner nutrient solution (25, 50 and $75 \%$ ) on gooseberry plants and found that the highest SPAD readings correspond to plants with the highest concentration of nutrient solution. 


\begin{tabular}{|c|c|c|c|c|c|c|c|}
\hline \multicolumn{8}{|l|}{$\begin{array}{l}\text { Modified } \\
\text { Variety }\end{array}$} \\
\hline \multirow{2}{*}{$\begin{array}{c}\text { Steiner's } \\
\text { nutrient solution } \\
\text { concentration (\%) }\end{array}$} & \multicolumn{3}{|c|}{ Vegetative stage } & \multicolumn{3}{|c|}{ Reproductive stage } & Fruiting stage \\
\hline & $\begin{array}{l}\text { Germination } \\
\text { (das) }\end{array}$ & $\begin{array}{l}\text { Transplant } \\
\text { (das) }\end{array}$ & $\begin{array}{l}\text { Preflowering } \\
\text { (ddt) }\end{array}$ & $\begin{array}{l}\text { Flowering } \\
\text { (dat) }\end{array}$ & $\begin{array}{c}\text { Fruit set } \\
\text { (dat) }\end{array}$ & Ripening (dat) & Fruiting (dat) \\
\hline 50 & 22 & 56 & 24 & 29 & 38 & 105 & 116 \\
\hline 100 & 22 & 56 & 23 & 27 & 38 & 101 & 109 \\
\hline 150 & 22 & 56 & 24 & 27 & 38 & 103 & 111 \\
\hline
\end{tabular}

Figure 4. Phenological stages in function of the concentration of Steiner solution in the Modified variety.

Antúnez-Ocampo et al. (2016) also evaluated the effect of the $\mathrm{NH}_{4}^{+}: \mathrm{NO}_{3}^{-}$rate in the Colombia variety of Physalis peruviana $L$. on SPAD readings during the entire crop cycle, and they did not find significant differences, although the highest readings (52.93) were found with nitrate (Steiner $50 \%$ ) at 75 dat; after 90 dat they observed lower readings, which is attributed to the $\mathrm{N}$ demands by the fruits. It should be mentioned that these readings are higher than those with treatments at 50\% in all the varieties in this experiment.

\section{Electric Conductivity (EC) and Sap pH}

The variance analysis for the variables $\mathrm{pH}$ and conductivity measured in sap extracted from stems and leaf petioles showed significant differences (Table 1) in terms of variety and solution, while the interaction of both did not have the same effect.

The variety factor affected both variables; the Modified variety registered the highest levels of $\mathrm{pH}$ (5.85) and sap conductivity (7.27), while the rest are statistically equal. On the other hand, the solution with the highest concentration reported the highest readings for both variables (Table 1).

The response of the Modified variety can be explained because it is morphologically different from the rest, it is most likely also genetically different, and therefore should be further studied. From the beginning, this variety showed growth and vegetative development similar to shell tomatoes (Physalis ixocarpa Brot.).

Although no studies have been carried out for these variables in sap from Physalis peruviana, $\mathrm{pH}$ is at a

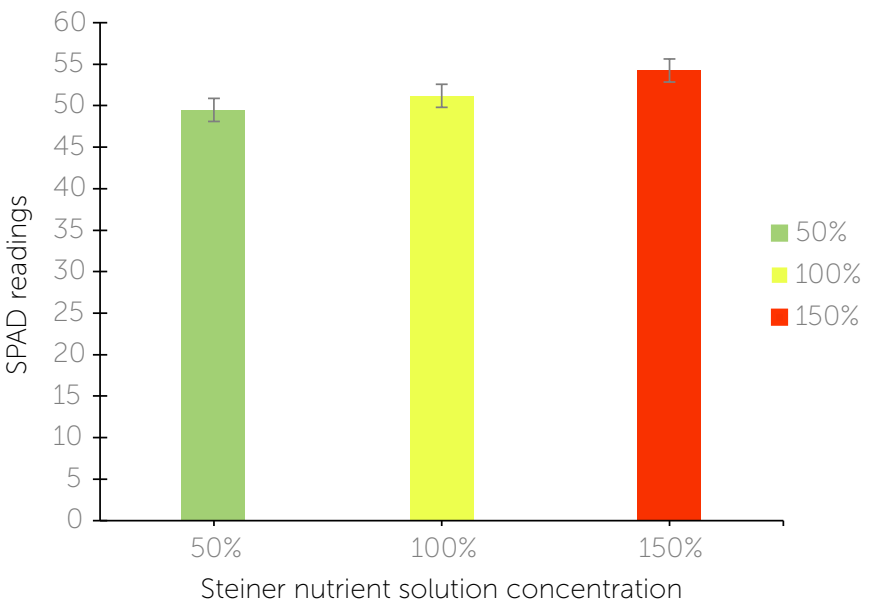

Figure 5. SPAD readings and their relationship with the concentration of the Steiner's nutrient solution.

\begin{tabular}{|c|c|c|c|}
\hline $\begin{array}{l}\text { Source of } \\
\text { variation }\end{array}$ & DF & $\mathrm{pH}$ in sap & $\begin{array}{l}\text { EC in sap } \\
\left(\mathrm{dS} \mathrm{m}^{-1}\right)\end{array}$ \\
\hline Variety & 3 & $0.0326^{*}$ & $0.0346 *$ \\
\hline Chiclayo & & $5.73 a$ & $6.83 b$ \\
\hline Colombia & & $5.73 \mathrm{a}$ & $6.89 a$ \\
\hline Modified & & $5.85 a$ & 7.27 a \\
\hline Sacha & & $5.72 \mathrm{~b}$ & $6.86 a$ \\
\hline Solution (\%) & 2 & $0.0009 *$ & $0.0001^{\star}$ \\
\hline 50 & & $5.66 \mathrm{~b}$ & $6.44 \mathrm{~b}$ \\
\hline 100 & & $5.79 a$ & $7.07 \mathrm{a}$ \\
\hline 150 & & $5.82 \mathrm{a}$ & 7.38 a \\
\hline Var*SN & 6 & $0.3538 \mathrm{~ns}$ & $0.1179 \mathrm{~ns}$ \\
\hline $\mathrm{CV}$ & & 2.05 & 5.78 \\
\hline
\end{tabular}

CV: coefficient of variation * P $\leq 0.05$; NS: P>0.05; DF: degrees of freedom. Medias with different letter in the same row are statistically different (Tukey, $p<0.05$ ). 
medial level for the 100 and $150 \%$ concentrations, while at $50 \%$ concentration there is a possible imbalance between cations. On the other hand, the electrical conductivity for sap from Physalis peruviana showed levels lower than those reported in the literature, where the optimal range reported should be between 12 and $15 \mathrm{dS} \mathrm{m}^{-1}$. This means that further studies are needed for this variable in order to have a reference value for other research.

\section{Plant Height and Base Diameter}

The variance analysis for plant height showed significant differences based on variety, solution and the interaction of both up to 24 dat (Table 2). At 31 dat only the nutrient solution's concentration showed any effect and at 52 dat no significant difference was seen in any factor.

The Sacha and Modified varieties at 4, 15, and 24 dat showed greater height, while the plants that achieved greatest height at 30 dat were with nutrient solution at 100 and 150\%. In posterior samples no factor affected plant height (Table 2). These data are superior to those reported by Mora et al. (2006) when six wild harvests of Physalis peruviana in hydroponics and fertigation were evaluated, where at 40 dat there were means of 34 and $43 \mathrm{~cm}$, and 75 and $80 \mathrm{~cm}$ at 64 dat.

On the other hand, after 30 dat the results were similar to those found by Antúnez (2013) in gooseberry, who reported that $\mathrm{NH}_{4}^{+}$and $\mathrm{NO}_{3}^{-}$did not influence consistently the plants' height, which means that the concentration of nutrients available is not important in terms of height.

The Chiclayo variety had a smaller base diameter at 4, 15, 24 and 31 dat, unlike the Modified variety, which had a thick stem; however at 52 dat there were no significant differences. Concerning the effect of concentration of the nutrient solution, after 24 dat the diameter was smaller with $50 \%$ solution and there were no differences at 100 and $150 \%$, and there is no interaction. These reports are superior to those by Mora et al. (2006) when evaluating six wild harvests of Physalis peruviana in hydroponics and fertigation; they reported means between 0.86 and $0.95 \mathrm{~cm}$ at 40 dat, and at 64 dat diameters varied between 1.30 and $1.33 \mathrm{~cm}$. On the other hand, Antúnez (2013) at $135 \mathrm{dat}$ registered diameters between 14.52 and $16.59 \mathrm{~mm}$ in plants originating from seeds.

\section{CONCLUSIONS}

The phenology of each variety was not expressed at the same time at any concentration, and as precocious varieties there are Chiclayo, Columbia and Sacha, which at 50 and $150 \%$ concentrations of nutrient solution had an average harvest at 99 dat. At 100\% concentration the Colombia variety was the most precocious with production at 93 dat, while the other two started 10 days later. The Modified variety was the latest variety, starting production at 112 dat.

\begin{tabular}{|c|c|c|c|c|c|}
\hline \multirow{3}{*}{$\begin{array}{l}\text { Source of } \\
\text { variation }\end{array}$} & \multicolumn{5}{|c|}{ Plant height $(\mathrm{cm})$} \\
\hline & \multicolumn{5}{|c|}{ Days after transplant } \\
\hline & 4 & 15 & 24 & 31 & 52 \\
\hline Variety & $0.0001^{*}$ & $0.0001^{\star}$ & $0.0175^{\star}$ & $0.7149 \mathrm{~ns}$ & $0.1189 \mathrm{~ns}$ \\
\hline Chiclayo & $3.65 c$ & $10.00 \mathrm{c}$ & $23.25 b$ & $40.75 a$ & $100.75 \mathrm{a}$ \\
\hline Colombia & $5.11 \mathrm{~b}$ & 11.77 b & 25.92 a & $42.00 \mathrm{a}$ & 99.42 a \\
\hline Modified & $5.68 \mathrm{~b}$ & $12.54 \mathrm{a}$ & $25.90 \mathrm{a}$ & $42.00 \mathrm{a}$ & 100.92 a \\
\hline Sacha & $6.78 \mathrm{a}$ & 13.07 a & 25.75 a & $41.00 \mathrm{a}$ & $94.83 a$ \\
\hline Solution (\%) & $0.0333^{*}$ & $0.0001^{\star}$ & $0.0001^{*}$ & $0.0001^{*}$ & 0.6314 ns \\
\hline 50 & $4.86 \mathrm{~b}$ & $10.76 \mathrm{~b}$ & $22.50 \mathrm{~b}$ & 37.94 b & 97.75 a \\
\hline 100 & $5.71 \mathrm{a}$ & 12.68 a & $27.11 \mathrm{a}$ & 43.44 a & 99.16 a \\
\hline 150 & $5.34 \mathrm{a}$ & $12.10 \mathrm{a}$ & $26.00 \mathrm{a}$ & $42.94 \mathrm{a}$ & $100.06 \mathrm{a}$ \\
\hline Var*SN & $0.0138^{*}$ & $0.0008^{\star}$ & $0.0262^{\star}$ & $0.2156 \mathrm{~ns}$ & $0.9407 \mathrm{~ns}$ \\
\hline CV & 16.56 & 9.01 & 9.15 & 8.14 & 6.89 \\
\hline
\end{tabular}

$C V$ : coefficient of variation * P $\leq 0.05$; NS: P>0.05; DF: degrees of freedom. Medias with different letter in the same row are statistically different (Tukey, $p<0.05$ ). 


\section{REFERENCES}

Ali, A. and Singh, B. P. (2014). Potentials of Cape gooseberry (Physalis peruviana L.): An underexploited small fruit in India. The Asian Journal of Horticulture 8(2): 775-777.

Antúnez O., O. M. (2013). Respuesta de Physalis peruviana L. con diferente origen: rebrote y semilla a diferentes formas de nitrógeno. Tesis de Maestría en Ciencias. Programa de Edafología. Colegio de Postgraduados. Montecillo, México. 107 p.

Antúnez O., O. M., M. Sandoval V., G. Alcántar G., J. Alvarado L., E. Sabino L. (2016). Floración y fructificación de Physalis peruviana L. por la aplicación de amonio y nitrato, edad y vigor de la planta. Agrociencia 50(5):603-615

Gastelum O. D. A., M. Sandoval V., C. Trejo L., R. Castro B. (2013). Fuerza iónica de la solución nutritiva y densidad de plantación sobre la producción y calidad de frutos de Physalis peruviana L. Revista Chapingo Serie Horticultura 19(2): 197-210. doi: 10.5154/r.rchsh.2012.01.002

Góngora, A., C. y P. Rojas G. (2006). Incidencia de las enfermedades en uchuva Physalis peruvianum L. por estado fenológico y de acuerdo con la ubicación en los diferentes estratos de la planta, en el departamento de Cundinamarca. Trabajo de grado. Facultad de Ciencias Biológicas, Pontificia Universidad Javeriana, Bogotá, Colombia. 87 p.

Mora, A., R., A. Peña L., E. López G., J. Ayala H., y D. Ponce A. (2006). Agrofenología de Physalis peruviana L. en invernadero y fertirriego. Revista Chapingo, Serie Horticultura 12:57-63. doi:10.5154/r.rchsh.2005.10.011

Morton F., J. (1987). Cape Gooseberry, pp. 430-434. In: Fruits of Warm Climates. MORTON F., J. (Edit). University of Miami. Media Incorporated. Miami, FL.

Sabino L., J. E., M. Sandoval V., G. Alcántar G., C. Ortiz S., M. Vargas H., T. Colinas L. (2016). Fenología de Physalis peruviana L. cultivada con base en tiempo térmico. Revista Mexicana de Ciencias Agrícolas 17: 3521 3528.

Sánchez A., A. B. (2019). Manejo de Fusarium oxysporum sp. physali y Rhizoctonia solani en Physalis peruviana L. mediante nutrición mineral. Tesis de Maestría en Ciencias. Programa de Fisiología Vegetal. Colegio de Postgraduados. Montecillo, México. 78 p.

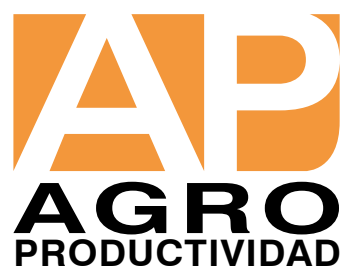

